\title{
Parents' Knowledge of the Risks that Children face when their Internet Exposure is Unregulated
}

\author{
Ms. Eva Kiti \\ (Department of Communication Studies, Moi University, Kenya)
}

\begin{abstract}
The level of reliance on the internet as a major source of information and entertainment has tremendously increased all over the world in the past years. Children in particular are encouraged to use the internet for purposes of accessing educational materials and socializing with friends and relatives. However, some of them come across material which may not necessarily be safe for the under aged. Similarly, others meet people online who may not have positive influence on them. In other words, in as much as the internet is beneficial to children, there are a number of risks that they face from time to time. It is thus agreeable that parents should have knowledge of such risks and as a result regulate the internet content to which their children get exposed. This paper examines the level of awarenessof such risks among parents in upmarket areas. The discussions are based on literature review and a study carried out at an up market residential area in Nairobi, Kenya in August 2015.
\end{abstract}

\section{INTRODUCTION}

The need for accessing the internet has become inevitable in this time and age. This is majorly because people have developed preference for networking channels which do not necessarily compel physical contacts. In fact most people consider the process of physical interactions more tedious and time consuming. As such, a lot of human activities are undertaken via computerized media. A lot of information has also been made accessible over the internet as a means to ensure efficiency in communication and information sharing. Similarly, various technologies have been advanced to promote social interactions, business dealings and entertainment platforms for all people. Like everyone else, the children have also become highly dependent on the internet. Initially, only adults were able to access the internet because computers were the major media of access. However, with the advent of more affordable portable devices, it has become much easier for children to access the internet at all times (Livingstone, 2013). For instance, the study that informs this paper was carried out in 2015 and it indicates that about $88.9 \%$ of children in Nairobi's upmarket areas go into the internet on a daily basis. These children get access to the internet both at home and in school. They thus expose themselves to diverse contents, some of which may be harmful to them. Notably, some parents are aware of these risks while others are not and this is as a result of various circumstances or reasons, which are brought out in this paper.

\section{INTERNET SITES COMMONLY ACCESSED BY CHILDREN}

There are several internet sites that children access. They include social media, educational sites and entertainment sites. These sites are outlined herein under.

\section{a. Social Media}

According to the businessdictionary.com, social media is defined as tools and applications used to share information online. The social sites are many, including facebook, twitter, WhatsApp and telegram among othersThese mediagive room forconnection, posting and sharing of information between people worldwide. Facebook particularlyallows peopleas young as those that are 13 years old to create accounts and access information thereon. In Europe alone, about 59\% of 9-16 year olds have social networking profiles (Livingstone et al, 2011). In Nairobi's upmarket areas, about $57.1 \%$ of the children love social sites the most.

\section{b. Educational/Informative Sites}

There are sites that offer school related educational materials such as text books for various school subjects and revision exercises. There are also sites that teach children about general life skills while others give them religious guidance. According to the survey undertaken in this study, $22.2 \%$ of the children often visit educational sites.

\section{c. Entertainment Sites}


Entertainment sites give children access to games, music, pictures, videos, movies and stories. Examples include youtube, flickr, facebook, WhatsApp and twitter among others. About $18.5 \%$ of the children interviewed in this study attested to the fact that they visit entertainment sites from time to time.

\section{THE MEDIA THROUGH WHICH CHILDREN ACCESS THE INTERNET}

The following gadgets are most commonly used by children in their endevours to access various internet sites:

- Desktop computers and laptops

- Cell and Mobile phones

- Televisions

- Tablets

- I-Pads

The computers are accessed both at school and at home. There are children who also visit cyber cafes in their neighborhoods in order to have access to computers while others get the computers from their friends' homes.The televisions are found in literally all homes and some families have their televisions internet enabled. This makes it even easier for the children to access the internet because about $98 \%$ of the children aged 9 years and above are capable of operating televisions. The cell phones, mobile phones, tablets and I-Pads are in most cases owned by the parents but are easily given to children to play games or access various sites in the internet. A focused group discussion held with parents in this study revealed that at least $90 \%$ of the parents willingly give their phones to their children, some of whom are as young as 5 years old. Other parents also buy mobile phones for their children.

\section{THE PURPOSES FOR WHICH CHILDREN ACCESS THE INTERNET}

Children visit different sites for different reasons. This is mainly because one set of sitestend to offer unique contents which may not be found in another set.First and foremost, the most visited sites are social media. The main reasons for visiting them include:

- To interact with friends online

- To share photos, videos and other information with friends

- For leisure

- For entertainment

- For learning purposes

This study revealed that about $54 \%$ and $2.6 \%$ of the children visited social media for purposes of interacting with friends and for entertainment respectively. The rest said they visit social sites for leisure and learning purposes.Secondly, children visit educational sites, in order to find answers for their school assignments. There are also sites that they access when taking computer related lessons in school. Lastly, the entertainment sites are visited by children majorly for entertainment through music, videos and movies. There are also a few children who reported in this study that they visit entertainment sites so that they can learn from their mentors in the entertainment industry. For instance, there are those who said that they visit youtube in order to watch the way particular musicians sing so that they can learn from them.

\section{THE NATURE OF THE INTERNET RISKS CHILDREN FACE}

While it may not be the wish of a child to encounter harmful contents when browsing the internet, it is an undeniable fact that every time they get online they face the risk of coming across material that can affect them negatively. In fact some of these contents may not just be upsetting to them but may also go as far as ruining their mindset and their lives in general (Rogers, et al, 2010). The risks are numerous, are of varying natures and have different degrees of harm on the child. They are discussed herein below.

\section{Pornography}

Pornography is defined as movies, pictures, magazines, etc., that show or describe naked people or sex in a very open and direct way in order to cause sexual excitement (Merriam Webster Dictionary). It is a universally accepted fact that children of underage are not supposed to be exposed to sexual material since they stand high chances of engaging in risky sexual activities, which they may not know how to handle because of their young age and inexperience(Ross, 2012). According to a study carried out in 25 countries in Europe by Livingstone et al in 2011, $14 \%$ of 9-16 year olds were reported to have seen online images that are "obviously sexual. These were inclusive of images showing naked people or people engaging in sexual intercourse.The study further revealed that one out of threechildren who saw the sexual images were troubled by the experience and others were very upset by such images. In the study carried out in Nairobi's upmarket residential area, $15.3 \%$ of the respondents mentioned pornography as one of the risks that children face every time they access the internet.The effects that pornographic materials have on children vary from one age group to another. Research has shown that teenagers are less bothered by sexual images or videos than younger children. 
Parents' Knowledge of the Risks that Children face when their Internet Exposure is Unregulated According to Ross, 2012, most of the teenagers that get exposure to the sexual content are highly likely to engage in regular sexual activities and begin abusing drugs as a way to enhance their sexual urge. Thus, exposure to pornographic materials is highly capable of destroying a teenager's life.

\section{Cyberbullying}

Cyberbullying refers to the use of technology to harass, threaten, embarrass, or target another person (Hirsch, 2014). Cyberbullying takes different forms, ranging from unkind, mean, or nasty messages, tweets, or responses to a status update on social media; to pretending to be someone else or posting confidential information, images, or videos meant to hurt or humiliate another person. Several kids have fallen victims of such acts yet some cases go unreported. In the Nairobi study, $11.1 \%$ of the respondents confirmed that cyberbullying is a constant threat to children with frequent access to the internet.In as much as cyberbullying may sound to be a simple thing, its long-term effects can be severe. According Hirsch (2016), it has the potential to cause anxiety, depression, and other stress-related disorders to both victims and bullies. There are even instances where cyberbullying has resulted in suicide among certain children.

\section{Sex texting}

The other risk that children face so often is sex texting. Also known as sexting, this is the act of the sending or receiving of sexually explicit or sexually suggestive images, messages, or video via a cellphone or the internet (Hirsch, 2014). Such include photos and videos that show nudity, sexual acts and simulations or text messages that present sexual proposals. About 15\% of 11-16 year olds in Europe have received sexual messages or images from peers. They also talk about having sex or images of naked people. Another $3 \%$ are reported to have sent such posts or texts to others(Livingstone S. H., 2011). The reactions to such messages vary from one kid to another. There are those that who get upset, some blacklist the senders of such messages, othersdelete the unwanted sexual messages while others get enticed are lured into sexual activities.

\section{Cybercrimes}

Cybercrimes are defined as offences committed against a person or people, with the intention of disgracing them orhurting them physically or mentally, or causing them a loss, either directly or indirectly, viatheinternetor mobile phones(Halder, 2011). Examples of such offences include copyright infringement, hacking and child pornography. According to Miami-Dade Schools Police Department, children are particularly susceptible to the following types of cybercrimes:

- Cyberbullying

- Cyberstalking

- Online predators

Cyberstalking entails harassing a person using electronic media like e-mails and messages posted in a web-site in which case the stalker takes advantage of the anonymity the is made possible by the internet. When such communications lack legitimate purpose, are malicious, and are capable of causing the victim significant emotional disturbance, they are considered are criminal offences.In regards to online predation, the offenders are said to commit the crimes by actively seeking after minors via the internet and tricking them into face to face meetings so that they can harm them or their families in one way or another(Jimenez, 2015). Some of the harmful activities that the predators do to children include child sexual abuse,child trafficking, drug abuseand other forms of exploitation which often results in children's taking part in age inappropriate playoffs. About $46.6 \%$ of the respondents in this study felt that children face the risk of cybercrimes. It is notable that while most of them may be victims, there are others who stand a chance of getting lured into practicing such criminal activities.

\section{THE POSSIBLE IMPACTS OF THE INTERNET RISKS TO CHILDREN}

The internet risks are not only in themselves harmful but are also capable of having other negative impacts of a child. Some of these impacts include character decay, irresponsibility,unsocial behaviour, health problemsand possibility of death.

\section{Character Decay}

One of the disapprovals frequently leveled against the internet and other electronic media is that they perpetuate moral decay among children and adults alike.Children have readyaccess tocontent thatpromote violence, sexual immorality and theft among other immoral behaviour (Wilson, 2008). Several studies have pointed to the fact that such material corrupts the mind of a young child who gets used to them and with time begins to consider them as acceptable norms of the society. Eventually, they begin to act in such inappropriate manners and more often than not, it becomes too late to make them deviate from such activities. 


\section{Lack of concentration on School Work and General Irresponsibility}

Experts have reported that the time that children spend on the internet has a great potential to distract them from educational activities. Secondly, there are websites which have been designed to enhance cheating and plagiarism. Access to such websites can greatly make the child lose his/her direction towards achieving his/her academic and career goals (Mercer, 2016). Children also end up wasting a lot of precious time which they could have used to develop themselves or engage in more important life activities such as helping with house chores, learning important life skills and so on.

\section{Unsocial Behaviour}

Availability of the Internet and social networking sites enableschildren tomake very many virtual friends from all over world. They are thus able to exchange a lot of information with both the people they know and those they don't know. They are also able to share their joys and sorrows with them, as well as secrets. As such, they find very little time to actively engage in actually discussions with family and friends who are close by. A lot of times they also get themselves into trouble but are unable to share with their parents or the adults around them because they are convinced that some of the solutions are readily available in the internet. As such, they are most of the time withdrawn from real interactions(Nguyen, 2016).

\section{Lack of Creativity and Personal Development}

Most children have become so dependent on the internet whenever they are doing school assignments and tackling various life challenges. In fact so many of them have fallen victims of examination cheating one time or another. They often get into the examination rooms with internet enabled gadgets such as mobile phones and make reference to internet material when answering examination questions. As a result, their creativity levels remain low since they hardly engage their minds in solving problems. They are therefore unable to achieve the level of personal development that an actively thinking person is able to achieve(Nguyen, 2016).

\section{Health Problemsand Possibility of Death}

Crimes such as cyberbullying cause some children a lot of anxiety, stress and depression. This is obviously unhealthy as it may lead to complications such as high blood pressure and mental illness. Withdrawal from physical contact is also unhealthy. For instance, if a child is unable to share his or her problems with his/her parents, they end up suffering in silence. When health complications set in, they stand chance of dying. Similarly, some of them resort to suicide.

\section{VII. PARENTS' AWARENESS OF THE RISKS AND THEIR IMPACTS ON CHILDREN}

Given that the use of inter is so widespread, the general knowledge about the internet risks can be said to be significantly sufficient. However, there are a certain portion of parents who totally are unaware of these risks. Moreover, there are risks that are known by almost everyone while others are known by only a few who may be frequently interacting with the internet. In this study there is assurance that most parents are aware about the risks associated with children's unregulated exposure to internet. The finding of the study shows that $97 \%$ of parent attested to the fact that there existed risks for children who are not regulated online. This owns to the fact that most of the parents mentioned how they monitored their children's exposure to internet. The results further showed that one of reason for parents monitoring their children online was to give children guidance on the contents that they were likely to encounter online. However, the lower proportions of parents who did not attest to the existence of risk among children unregulated exposure to internet, points to a gloomy picture of reluctance in solving problems of children risks on unregulated exposure to internet.

\section{The Reasons as to why Some Parents are Aware of the Risk while others are not Literacy levels}

Some parents are unable to track the online risks that their children face because they are not conversant with internet. In fact some of them rely on their children to understand the varies internet application in their phones. Most of the children with such parents thus tend to take advantage of their parents' inabilities and engage in as many internet activities as possible. On the other hand, parents who are more conversant with internet can trace their children's activities more easily.

\section{Lack of Knowledge of online vocabulary used by kids}

Other reports show that some parents are unaware of internet risks because they don't understand some of the online vocabulary used. As a result, they fail to protect their children in cyberspace(Booth, 2013). Examples of such vocabulary include:

- LMIRL - Let's Meet In Real Life

- Frape - A combination of the words 'Facebook' and 'Rape' 
- YOLO - You Only Live Once

- ASL - Age, Sex, Location

\section{Conformity to technological changes}

The rate at which the technological advancements take place is so high that some parents are unable to keep pace. These advancements come with new risks which the parents may not be aware of. As such, it becomes less and less likely that they will even track their children's activities online. For example, there are parents who have only learnt basic computer applications (e.g. Microsoft Word) and it is only because they are required to use them from time to time. Such parents are reluctant to learn any new applications. Children on the other hand are so curious that they want to grasp every new technology that they come across. The result is that the parents never match their children's in the knowledge and thus it is hard for them to know what they do or don't do online.

\section{Level of regulation of children's activities}

Some parents are also unaware of the online risks that their children face because they never track their activities. Some of the parents are too busy to find time to interact with their children, let alone sitting with them while they browse the internet.Other parents are also reluctant to track the online activities that children undertake because they trust their children will always do the right things. However, some children misuse this trust and engage in wrong activities online.

\section{The Risks known by majority of Parents versus those known by only a few}

There are risks that most parents while others are only known by a few. According to Eurobarometer (2008),the internet risks that are most commonly known by parents are outlined as follows:

- Exposure to sexually/violently plain images on the Internet

- Chances of children becoming victims of online grooming. Grooming refers to a situation whereby somebody creates an emotional relationship with a child so that he/she can be trusted by the child and thereafter the child can be lured into sexual activities.

- Susceptibility to bullying

- Prospects of getting information about self-harm, drug abuse and suicide

- High prospects of anorexia (A medical condition which causes lack or loss of appetite for food)

- High chances of children becoming isolated from others when spending too much time online

- Possibility of children revealing personal or private information when using the internet On the other hand, there are risks that parents may not think are potentially harmful to their children. Such include:

- Online Gambling: gambling refers to the process of betting of money or something with a cetain value on an occurrence with an uncertain result with the aim of winning extra money or material(Berglun, 2016). As such children are most vulnerable to such risks because they don't have resources to use in gambling. However, what may be hidden to many is that some children would go as far as stealing from their parents in order to get money or the material thy can bet on.

- Online Predation: According to Spencer (2012), many parents are unaware of online predators, despite the widespread use of the internet. One of the reasons behind this scenario is that most children have been cautioned against meeting strangers and so in the event that someone lures them into offline meetings, they will shy away from letting their parents know.

\section{CONCLUSION}

It is agreeable that times have changed and parents have much more to worry about their children than it was a number of years ago. The advent of electronic media and the popularity thereof is both beneficial and harmful, especially to the children who may not have the capacity to control whatever dangers that come their way. From the above discourse, children become more and more susceptible to invisible dangers that arise with technological advancements. It is thus necessary that parents rise to the occasion in monitoring their children's activities on the internet so that they can help them avoid certain harms. In instances where the parent is unable to monitor their children, other institutions such as schools and the government may need to come in. in other words, there is a pressing need for collective effort geared towards protecting children from internet risks and dangers associated with the use of various electronic media. Furthermore, the children need to be taught on how to be extra vigilant so that in the event that nobody is around to help them, then they can fight their own battles successfully.

\section{REFERENCES}

[1] Livingstone, S. (2013). Children and the Internet. New York, NY: John Wiley \& Sons. 
Parents' Knowledge of the Risks that Children face when their Internet Exposure is Unregulated

[2] Livingstone, S., Haddon, L., Görzig, A., and Ólafsson, K. (2011). Risks and safety on the internet: Theperspective of European children.Full Findings. LSE, London: EU Kids Online

[3] Rogers, V. (2010).Cyberbullying: Activities to help children and teens to stay safe in a texting, twittering, social networking world. London: Jessica Kingsley Publishers.

[4] Ross, C. C. (2012, August Monday). Psychology Today. Retrieved October Sunday $23^{\text {rd }}$, 2016, from https://www.psychologytoday.com/blog/real-healing/201208/overexposed-and-under-prepared-theeffects-early-exposure-sexual-content.

[5] Hirsch, L. (2014, June). Kids Health . Retrieved October Sunday, 2016, from http://kidshealth.org/en/parents/cyberbullying.html

[6] Halder, D., \& Jaishankar, K. (2011) Cyber crime and the Victimization of Women: Laws, Rights, and Regulations. Hershey, PA, USA: IGI Global. ISBN 978-1-60960-830-9

[7] Jimenez, D. (2015). Miami-Dade Schools Police Department. Retrieved October Sunday $23^{\text {rd }}$, 2016, from http://mdspolice.com/wp-content/uploads/2015/06/VIP305-2015-061.pdf

[8] Wilson, B. J. (2008). Media and Children's Aggression, Fear and Altruism. Children and Electronic Media

[9] Mercer, E. (2016). Tech in Our Everyday Life. Retrieved October Sunday $23^{\text {rd }}$, 2016, from Demand Media, Inc: http://techin.oureverydaylife.com/physical-social-effects-internet-use-children-1471.html

[10] Nguyen, L. (2016, July 19). Vkool. Retrieved October $23^{\text {rd }}$, 2016, from http://vkool.com/negative-effectsof-internet/\#badwebs

[11] Eurobarometer. (2008). Towards a Safer Use of the Internet for Children in the EU: A Parents' Perspective. Luxembourg: European Commission Safer Internet Programme.

[12] Booth, R. (2013, July Thursday 11). The Guardian. Retrieved October Sunday 23rd, 2016, from https://www.theguardian.com/society/2013/jul/11/children-risk-parents-internet-speak

[13] Berglun, B. (2016, March). Future of Business and Tech. Retrieved October Sunday 23rd , 2016, from http://www.futureofbusinessandtech.com/online-and-mobile-safety/parents-wake-up-the-hidden-dangersonline

[14] Spencer, S. (2012, May 31st ). CovenantEyes. Retrieved October 23rd, 2016, from http://www.covenanteyes.com/2012/05/31/are-parents-really-aware-of-how-many-predators-there-are-onthe-internet/ 